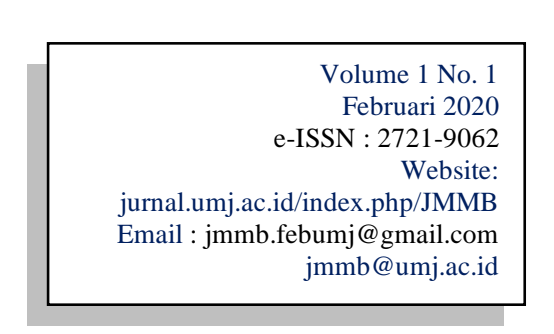

\title{
PENGARUH INFORMASI NON KEUANGAN TERHADAP MINAT BERINVESTASI DALAM BURSA EFEK INDONESIA
}

\author{
Alistraja Dison Silalahi ${ }^{1, *}$, Debbi Chyntia Ovami ${ }^{2}$ \\ ${ }^{1}$ Akuntansi, Ekonomi, Univeristas Muslim Nusantara Al Washliyah, Jl.Garu IIA No 93, Medan, 20147 \\ ${ }^{2}$ Akuntansi, Ekonomi, Univeristas Muslim Nusantara Al Washliyah,Jl Garu IIA No 93, Medan, 20147 \\ *Alistraja.disonsilalahi@gmail.com
}

\begin{abstract}
ABSTRAK
Penelitian ini bertujuan untuk untuk mengetahui pengaruh informasi non keuangan terhadap minat berinvestasi di Bursa Efek Indonesia (Studi KasusMahasiswa Fakultas Ekonomi Universitas Muslim Nusantara Al-Washliyah Medan). Metode penelitian yang digunakan dalam penelitian ini adalah deskriptikuantitatif. Populasi dalam penelitian adalah Mahasiswa Fakultas EkonomUniversitas Muslim Nusantara Al-Washliyah Medan. Teknik sampel dalampenelitian ini adalah sampling incidental dimana sampel dalam penelitian inadalah Mahasiswa Fakultas Ekonomi Universitas Muslim Nusantara AlWashliyah Medan angkatan 2015 sebanyak 10\% yang berjumlah 73 mahasiswaSumber data yang digunakan adalah data primer berupa hasil kuesioner, observasdan wawancara, metode analisis data dalam penelitian ini yaitu regresi liniesederhana yang berupa uji $\mathrm{t}$ (persial), dan uji koefesien determinan.Hasipenelitian menunjukkan bahwa informasi non keuangan berpengaruh posititerhadap minat berinvestasi di bursa efek Indonesia pada mahasiswa fakultas ekonomi universitas muslim nusantara al-washliyah medan.
\end{abstract}

Kata Kunci : Informasi Non Keuangan, Minat Berinvestasi

\section{ABSTRACT}

This study aims to determine the effect of non-financial information on investing interest in the Indonesia Stock Exchange (Case Study of Students of the Faculty of Economics, Muslim University Nusantara Al-Washliyah Medan). The research method used in this study is descriptive quantitative. The population in the study was students of the Faculty of Economics, Muslim University Nusantara Al-Washliyah, Medan. The sample technique in this study was incidental sampling where the sample in this study were students of the Faculty of Economics, Al-Washliyah Muslim Nusantara Medan, class of 2015 as much as 10\%, amounting to 73 students. Sources of data used are primary data in the form of questionnaires, observations and interviews, data analysis methods in this study are simple linear regression in the form of t test (persial), and determinant coefficient tests. The results show that nonfinancial information has a positive effect on interest in investing on the Indonesian stock exchange on students of the economic faculty of Muslim universities in the archipelago al-washliyah medan.

Keywords : Non-Financial Information, Interest in Investing 


\section{PENDAHULUAN}

Perkembangan ekonomi dan teknologi komunikasi yang sangat pesat memberikan begitu banyak kemudahan dalam dunia bisnis. Hal ini terlihat dengan banyaknya perusahaanperusahaan yang berdiri dan berkembang dengan memanfaatkan fasilitas teknologi. Selain itu, perkembangan bisnis ini juga berdampak pada meningkatnya daya saing antar perusahaan sehingga setiap perusahaan dituntut untuk selalu mengembangkan strateginya. Salah satu bentuk strategi perusahaan dalam menunjang kinerja perusahaan adalah dengan bergabung dipasar modal.

Hadirnya pasar modal memiliki peranan penting bagi para investor, baik investor individu maupun badan usaha. Mereka dapat menyalurkan kelebihan dana yang dimilikinya untuk diinvestasikan, sehingga para pengusaha dapat memperoleh dana tambahan modal untuk memperluas jaringan usahanya dari para investor yang berada dipasar modal (Pajar, 2017). Investasi merupakan salah satu dari instrument pembangunan yang dibutuhkan oleh suatu negara dalam rangka meningkatkan

kesejahteraanmasyarakatnya, termasuk Indonesia. Secara sederhana investasi diartikan sebagai penanaman modal (Suherman, 2013).

Salah satu bentuk investasi yang sering digunakan adalah investasi dipasar modal. Semenjak dibukanya Bursa Efek Indonesia, jenis investasi ini merupakan salah satu alternatif investasi yang mudah diakses oleh masyarakat luas.

Edukasi tentang pasar modal kepada masyarakat adalah hal yang penting dicanangkan karena bermanfaat untuk meningkatkan jumlah peminat agar berinvestasi di pasar modal (Tandio, 2016). Oleh karena itu, pemerintah melalui Bursa Efek Indonesia mencanangkan sebuah program gerakan kampanye yakni "Yuk Nabung Saham"dalam rangka meningkatkan jumlah investor di pasar modal Indonesia. kampanye ini bertujuan untuk memberikan motivasi, mengedukasi dan mengembangkan industri pasar modal, sekaligus menambah investor baru yang menyasar kesegmentasi generasi muda, seperti pelajar, mahasiswa, dan karyawan usia muda.

Salah satu yang menjadi obyek sasaran utama PT Bursa Efek Indonesia dalam menjaring investor-investor baru adalah dengan mendirikan Galeri Investasi yang ada disetiap Universitas. Direktur pengembangan Bursa Efek Indonesia (Danang,2016) menyatakan, mahasiswa dapat menjadi potensi besar sebagai investor pasar modal baru. Hal ini dapat terwujud dengan semakin bertambah banyaknya Galeri Investasi yang dibangun. Dengan demikian jumlah investor baru dari kalangan mahasiswa juga semakin meningkat. Walaupun belum punya pendapatan tetap, tapi minat dari mahasiswa untuk berinvestasi cukup tinggi.

Akuntansi sebagai cabang ilmu yang tujuan utamanya mengumpulkan mengolah dan mengeluarkan informasi atas berbagai transaksi bisnis perusahaan. Informasi ini berguna dalam upaya pengambilan kebijakan, baik oleh manajemen maupun pemerintah dan investor. Dengan semakin dibutuhkannya kajian dibidang perilaku khususnya bidang akuntansi dan keuangan maka bentuk dan isi dari laporan yang diungkapkan perusahaan sangat berdampak terhadap keputusan investasi, artinya dalam rangka pengambilan keputusan investasi yang tepat dan efektif investor harus memikirkan bentuk baku dan isi dari laporan non keuangan.

Saat ini para investor dalam pengambilan keputusan lebih cenderung menggunakan laporan keuangan perusahaan, disisi lain mereka telah muncul mengubah pandangan bahwa informasi non keuangan lebih penting dan cukup banyak digunakan oleh investor (Ikbal, 2017). 
Istilah informasi non keuangan mampu membentuk nilai perusahaan dalam jangka panjang. Informasi non keuangan menggambarkan kinerja masa depan perusahaan, dan pada saat yang sama menggambarkan bahwa perusahaan telah dikelola dengan baik (Ikbal, 2017). Dalam penelitian ini, dipilih tiga jenis informasi non keuangan yang memungkinkan bagi investor berguna dalam pengambilan keputusan untuk berinvestasi di Bursa Efek Indonesia antara lain: indikator kinerja ekonomi, tata kelola perusahaan, dan informasi CSR.

Informasi non keuangan merupakan salah satu faktor kunci untuk menetapkan strategi yang dipilih guna pelaksanaan tujuan yang ditetapkan dan dapat dihubungkan dengan informasi keuangan dalam merancang sisitem pengukuran kinerja. Penggunaan informasi keuangan meningkat untuk digunakan pada manajemen yang lebih rendah dan informasi non keuangan digunakan untuk kontrol manajemen yang lebih tinggi. Menurut Ikbal (2017:182) ada beberapa jenis laporan atau informasi non keuangan yang memungkinkan bagi investor berguna dalam pengambilankeputusan berinvestasi yaitu: indikator kinerja ekonomi, tata kelola perusahaan, dan informasi CSR.

$$
\text { Menurut Ikbal (2017:182) }
$$

Informasi non keuangan berpengaruh terhadap minat berinvestasi. Dimana informasi non keuangan merupakan salah satu faktor kunci untuk menetapkan strategi yang dipilih guna pelaksanaan tujuan yang ditetapkan dan dapat dihubungkan dengan informasi keuanagan dalam merancang sistem pengukuran kinerja, informasi non keuangan juga memungkinkan bagi investor berguna dalam pengambilan keputusan berinvestasi. Sedangkan menurut Husnan (2016:87) Informasi non keuangan merupakan informasi diluar data keuangan perusahaan. Investor dapat memperoleh informasi non keuangan tersebut melalui prospektus yang diterbitkan oleh perusahaan. Informasi non keuangan yang ditawarkan pada prospektus bertujuan untuk menarik investor berinvestasi ke perusahaan.

Minat menurut Kusmawati (2011:104) memilki definisi sebagai kecendrungan hati yang tinggi terhadap sesuatu gairah, keinginan. Perluasan dari definisi minat adalah:

a. Minat dianggap sebagai perantara faktor-faktor mati rasional yang mempunyai dampak pada suatu perilaku. b. Minat menunjukkan seberapa keras seseorang berani mencoba.

c. Minat menunjukkan seberapa banyak upaya yang direncanakan seseorang.

Teori sikap yaitu Theory of Reasoned Action yang dikembangkan oleh Kusmawati (2011:104), mengungkap adanya keinginan untuk bertindak karena adanya keinginan yang spesifik untuk berperilaku. Hal ini menunjukkan bahwa niat berperilaku dapat menunjukkan perilaku yang akan dilakukan oleh seseorang. Hal ini juga berarti bahwa seorang yang memiliki minat berinvetasi maka kemungkinan besar dia akan melakukan tindakantindakan yang dapat mencapai keinginan mereka untuk berinvestasi, seperti mengikuti pelatihan dan seminar tentang investasi, menerima dengan baik penawaran investasi, dan pada akhirnya melakukan investasi.

\section{METODE PENELITIAN}

Model analisis data yang digunakan pada penelitian ini adalah model analisis regresi linier sederhana (Sugiyono, 2017:270). Tujuan dari teknik analisis regresi linier sederhana adalah bertujuan untuk mengetahui pengaruh antara informasi non keuangan terhadap minat berinvestasi dalam pasar modal. Untuk menguji hipotesis, digunakan Model Regresi Linier Sederhana dengan rumus sebagai berikut:

$\mathbf{Y}=\mathbf{a}+\mathbf{b X}$

Keterangan:

Y : Keputusan investasi investor individu

a : Konstanta 
b : Koefisien

X : Informasi Non Keuangan

Untuk pengujian validitas peneliti menggunakan SPSS 20 dengan rum Correlate, Bivariate Correlations,

Tabel 1

Hasil Uji Validitas Variabel Informasi Non Keuangan (X1)

\begin{tabular}{|c|c|c|c|}
\hline Pernyataan & $\begin{array}{c}\mathbf{R} \\
\text { hitung }\end{array}$ & R tabel & Ket. \\
\hline $\begin{array}{c}\text { Pernyataan } \\
\mathbf{1}\end{array}$ & 0,498 & 0,2997 & Valid \\
\hline $\begin{array}{c}\text { Pernyataan } \\
\mathbf{2}\end{array}$ & 0,604 & 0,2997 & Valid \\
\hline
\end{tabular}

Sumber : Data Diolah (2019)

Berdasarkan tabel 1 dimana nilai validitas pernyataan untuk kemampuan kerja seluruhnya sudah valid karena nilai validitas seluruhnya lebih besar dari $\mathrm{r}$

Tabel 2

Hasil Uji Validitas Variabel Kemampuan Kerja (X2)

\begin{tabular}{|c|c|c|c|}
\hline Pernyataan & $\begin{array}{c}\mathbf{R} \\
\text { hitung }\end{array}$ & $\begin{array}{c}\mathbf{R} \\
\text { tabel }\end{array}$ & $\begin{array}{c}\text { Kete } \\
\text { rang } \\
\text { an }\end{array}$ \\
\hline $\begin{array}{c}\text { Pernyataan } \\
1\end{array}$ & 0,864 & 0,2997 & Valid \\
\hline $\begin{array}{c}\text { Pernyataan } \\
2\end{array}$ & 0,933 & 0,2997 & Valid \\
\hline $\begin{array}{c}\text { Pernyataan } \\
3\end{array}$ & 0,863 & 0,2997 & Valid \\
\hline
\end{tabular}

Sumber : Data Diolah (2019)

Berdasarkan tabel 2 dimana nilai validitas pernyataan untuk kemampuan kerja seluruhnya sudah valid karena nilai validitas seluruhnya lebih besar dari $r$ tabel $(n-2=73-2=71=0,2997)$ dan bisa digunakan dalam perhitungan selanjutnya karena seluruhnya dinyatakan valid.

Tabel 3

Hasil Uji Reliabelitas Instrumen Variabel Informasi Non Keuangan

\begin{tabular}{|l|l|}
\multicolumn{2}{c}{$(\mathbf{X})$} \\
\hline $\begin{array}{l}\text { Reliability } \\
\text { Statistics }\end{array}$ & $\begin{array}{l}\text { Cronbach's Alpha } \\
\text { N of Items }\end{array}$ \\
\hline .625 & 5 \\
\hline
\end{tabular}

Dari tabel 3 diatas jelas bahwa terdapat nilai Cronbach's Alpha sebesar dengan memasukkan butir skor pernyataan totalnya pada setiap variabel. Berikut adalah hasil dari uji validitas

\begin{tabular}{|c|c|c|c|}
\hline $\begin{array}{c}\text { Pernyataan } \\
\mathbf{3}\end{array}$ & 0,632 & 0,2997 & Valid \\
\hline $\begin{array}{c}\text { Pernyataan } \\
\mathbf{4}\end{array}$ & 0,682 & 0,2997 & Valid \\
\hline $\begin{array}{c}\text { Pernyataan } \\
\mathbf{5}\end{array}$ & 0,744 & 0,2997 & Valid \\
\hline
\end{tabular}

tabel(n-2=73-2=71=0,2997) dan bisa digunakan dalam perhitungan selanjutnya karena seluruhnya dinyatakan valid.

0,625 hal ini menyatakan bahwa nilai Cronbach's Alpha > 0,6 maka dapat dikatakan bahwa instrumen penelitian yang digunakan yaitu reliable atau dapat dipercaya dimana tingkat reliable dari instrumen berada pada tingkatan sangat kuat sehingga instrumen penelitian pada informasi non keuangan dapat dijadikan sebagai data penelitian.

Tabel 4

Hasil Uji Reliabelitas Instrumen Variabel Minat Berinvetasi (Y)

\begin{tabular}{|l|l|}
\hline $\begin{array}{l}\text { Reliability } \\
\text { Statistics }\end{array}$ & $\begin{array}{l}\text { Cronbach's Alpha } \\
\text { N of Items }\end{array}$ \\
\hline .856 & 3 \\
\hline
\end{tabular}

Sumber : Data Diolah (2019)

Dari tabel 4 diatas jelas bahwa terdapat nilai Cronbach's Alpha sebesar 0,856 hal ini menyatakan bahwa nilai Cronbach's Alpha > 0,6 maka dapat dikatakan bahwa instrumen penelitian yang digunakan yaitu reliable atau dapat dipercaya dimana reliabelitas variabel minat berinvestasi berada pada tingkatan yang kuat untuk dijadikan data dalam penelitian.

HASIL DAN PEMBAHASAN 
Sebelum melakukan uji hipotesis, terlebih dahulu dilakukan uji kualitas data. Dari hasil uji kualitas data diperoleh hasil bahwa uji validitas, uji reliabilitas telah terpenuhi.

\section{Uji Koefisien Determinasi $\left(\mathbf{R}^{2}\right)$}

Hasil uji koefisien determinasi dapat dilihat pada Tabel 5

\begin{tabular}{|c|c|c|c|c|}
\hline $\begin{array}{l}\text { Mode } \\
1\end{array}$ & $\mathrm{R}$ & $\begin{array}{l}\mathrm{R} \\
\text { Squar } \\
\mathrm{e}\end{array}$ & $\begin{array}{l}\text { Adjuste } \\
\text { d R } \\
\text { Square }\end{array}$ & $\begin{array}{l}\text { Std. } \\
\text { Error of } \\
\text { the } \\
\text { Estimat } \\
\text { e }\end{array}$ \\
\hline 1 & .818 & .714 & .678 & 1.33022 \\
\hline
\end{tabular}

Sumber : Data Diolah (2019)

Dari tabel 5 menghasilkan nilai Adjusted R Square adalah sebesar 0.678 atau berarti $67.8 \%$ pengaruh variabel independen (Informasi Non Keuangan) terhadap variabel dependen (Minat Berinvestasi) sedangkan sisahnya $32.2 \%$ dipengaruhi dan dijelaskan oleh variabel lain yang tidak masuk dalam model penelitian ini

\section{Uji Parsial (Uji-t)}

Hasil uji parsial (Uji-t) dapat dilihat pada Tabel 6

Tabel 6. Hasil Uji-t

\begin{tabular}{|c|c|c|c|c|c|}
\hline & \multicolumn{2}{|c|}{$\begin{array}{c}\text { Unstandardized } \\
\text { Coefficients }\end{array}$} & $\begin{array}{c}\text { Standar } \\
\text { dized } \\
\text { Coeffic } \\
\text { ients }\end{array}$ & & \\
\cline { 2 - 5 } Model & $\mathrm{B}$ & $\begin{array}{c}\text { Std. } \\
\text { Error }\end{array}$ & Beta & $\mathrm{t}$ & Sig. \\
\hline $\begin{array}{c}\text { (Const } \\
\text { ant) }\end{array}$ & 8.943 & 3.047 & & 2.935 & .004 \\
\hline $\begin{array}{c}\text { Inform } \\
\text { asi } \\
\text { Non } \\
\text { Keuan } \\
\text { gan }\end{array}$ & .151 & .151 & .818 & 5.003 & .000 \\
\hline
\end{tabular}

Sumber : Data Diolah (2019)

Dari Tabel 6 menghasilkan pengaruh masing-masing variabel independen terhadap variabel dependen secara parsial adalah Nilai signifikansi Informasi Keuangan sebesar 0,00 lebih kecil dari $\alpha(0,05)$, maka $\mathrm{H}_{a}$ diterima.
Informasi Keuangan secara parsial berpengaruh positif dan signifikan terhadap keputusan investasi.

Model persamaan regresi di atas sebagai berikut

$$
Y=8.943+0.151 X
$$

Dari hasil pembahasan maka penelitian ini dapat disimpulkan bahwa $\mathrm{H}_{\mathrm{a}}$ diterima artinya ada pengaruh antara informasi non keuangan (X) terhadap minat berivestasi (Y). Dari hasil uji regresi linear sederhana dengan menggunakan perhitungan software SPSS versi 20 for windows memperoleh nilai sebesar $\mathrm{Y}=8,943+0,151 \mathrm{X}$, dimana hal ini berarti jika ditingkatkan informasi non keuangan sebesar satu satuan akan meningkatkan minat berinvestasi sebesar 0,151 atau $15,1 \%$. nilai perbandingan nilai $\mathrm{t}$ hitung dengan $\mathrm{t}$ table yaitu nilai $\mathrm{t}_{\text {hitung }}$ sebesar 5,003 $<\mathrm{t}_{\text {table }}$ sebesar 2,042.

Dari hasil penelitian diatas dapat dilihat bahwa informasi non keuangan berpengaruh positif dan signifikan terhadap minat berinvestasi yang artinya apabila perusahaan memberikan informasi non keuangan secara detail dan jelas dapat meningkatkan minat berinvestasi Mahasiswa Fakultas Ekonomi Universitas Muslim Nusantara Al-Washliyah Medan.

Hal ini dapat mempengaruhi nilai perusahaan dan dapat meningkatkan keuntungan bagi perusahaan dan investor. Apabila informasi non keuangan yang dimiliki perusahaan yang disajikan dapat menarik minat perinvestasi maka perusahaan tersebut dapat menarik mahasiswa Fakultas Ekonomi Universitas Muslim Nusantara Al-Washliyah Medan untuk berinvestasi dari sekarang ke perusahaan, serta dapat mengetahui keuntungan dalam mempelajari portofolio perusahaan.

$$
\text { Menurut Ikbal (2017:182) }
$$

Informasi non keuangan berpengaruh terhadap minat berinvestasi. Dimana informasi non keuangan merupakan salah satu faktor kunci untuk menetapkan strategi yang dipilih guna 
pelaksanaan tujuan yang ditetapkan dan dapat dihubungkan dengan informasi keuanagan dalam merancang sisitem pengukuran kinerja, informasi non keuangan juga memungkinkan bagi investor berguna dalam pengambilan keputusan berinvestasi.

Sedangkan menurut Husnan (2016:87) Informasi non keuangan merupakan informasi diluar data keuangan perusahaan. Investor dapat memperoleh informasi non keuangan tersebut melalui prospektus yang diterbitkan oleh perusahaan. Informasi non keuangan yang ditawarkan pada prospektus bertujuan untuk menarik investor berinvestasi ke perusahaan.

Menurut Kusmawati (2011:104) minat merupakan kecendrungan hati yang tinggi terhadap sesuatu gairah, keinginan. Dimana minat dianggap sebagai perantara faktor-faktor mati rasional yang mempunyai dampak pada suatu perilaku, minat juga menunjukkan seberapa keras seseorang berani mencoba, dan minat juga menunjukkan seberapa banyak upaya yang direncanakan seseorang. Hal ini menunjukkan bahwa niat berperilaku dapat menunjukkan perilaku yang akan dilakukan oleh seseorang. Hal ini juga berarti bahwa seseorang yang memiliki minat berinvestasi maka kemungkinan besar dia akan melakukan tindakantindakan yang dapat mencapai keinginan mereka untuk berinvestasi.

\section{KESIMPULAN}

Dari hasil pembahasan maka penelitian ini dapat disimpulkan bahwa Ha diterima artinya ada pengaruh antara informasi non keuangan (X) terhadap minat berivestasi (Y). Dari hasil uji regresi linear sederhana dengan menggunakan perhitungan software SPSS versi 20 for windows memperoleh nilai sebesar $\mathrm{Y}=8,943+0,151 \mathrm{X}$, dimana hal ini berarti jika ditingkatkan informasi non keuangan sebesar satu satuan akan meningkatkan minat berinvestasi sebesar 0,151 atau $15,1 \%$. nilai perbandingan nilai $t$ hitung table yaitu nilai thitung sebesar 5,003 $<\mathrm{t}$ table sebesar 2,042.

\section{DAFTAR PUSTAKA}

Ikbal,Muhammad.(2017).Apakah Informasi Non Keuangan Berguna Bagi Investor Survei Persepsi Bagi Investor Retail Di Indonesia.Fakultas Ekonomi dan Bisnis Universitas Mulawarman Samarinda.Vol.14.

Kusmawanti.(2016).Pengaruh Motivasi Terhadap Minat Berinvestasi Di Pasar Modal dengan Pemahaman Investasi dan Usia sebagai Variabel Moderat.Jurnal Ekonomi dan Informasi Akuntansi (JENIUS).Vol.1.

Pajar Chaerul, Rizki.(2017).Pengaruh Motivasi Investasi dan Pengetahuan Investasi Terhadap Minat Investasi Di Pasar Modal pada Mahasiswa FE UNY.Jurnal Profita Edisi I.

Sugiyono.(2017).Metode Penelitian Kuantitatif.Kualitatif dan $R \quad$ \& $D$.Alfabeta.Bandung.

Suherman, Herman et all.(2013).Strategi Pembelajaran Matematika Kontemporer.Jurusan Pendidikan Matematika Fakultas Pendidikan Matematika dan Ilmu Pengetahuan Alam:Universitas Pendidikan Matematika Indonesia.

Sunyoto, Danang.(2016).Metodelogi Penelitian Akuntansi.Bandung:PT Refika Aditama.

Tandio, T.(2016).Pengaruh Pelatihan Pasar Modal, Return, Perseps Risiko, Gender dan Kemajuan 